entrusted to the care of the Federal Governor. It is evident that while the Government is in sympathy with the principle, difficulty has been felt as to the limits to which its application is a practical possibility. The Under Secretary to the India Office (Mr. Butler) explained what these difficulties are. While mainly administrative, especially where 'pockets' of aboriginal tribes live among a more advanced population, they also entail the possibility of a retrocession where some cultural advance has already been made.

Lord Eustace Percy pointed out that it had not been possible to provide the House with the detailed information requisite for a decision on the detailed amendment of the schedule; and it is probable that the wisest course was followed in the adoption of the suggestion of the Attorney General (Sir T. Inskip) to withdraw the question from immediate discussion by the omission of the schedule from the Bill and the preparation of an Order in Council for submission to the House after all necessary information had been obtained. Members thus have the assurance that they will at least be in full possession of the facts, and the "anthropologists" will be in a position to gauge how far it will be possible to avert the danger of oppression, which is feared, through clash of culture, under the Provincial Governments. In the meantime, the important pronouncement has been made that the policy of the Government in dealing with the question of the aboriginal tribes is assimilation rather than segregation.

\section{Aborigines and the Law in Australia}

IT is evident that public opinion in Australia has been stirred by recent decisions of the courts in criminal cases in which aborigines have been implicated. Two aborigines undergoing sentence for killing a goat have been released from Port Augusta gaol, according to an Adelaide cable in The Times of May 7, by the Governor of South Australia, MajorGeneral Sir William Dugan, in response to a petition from the Aborigines Friends Association. It was stated that the crime was committed under stress of great hunger and in ignorance of the white man's laws. This decision has renewed interest in the case of the two aborigines recently condemned to ten years imprisonment for killing a fellow-tribesman who had revealed ritual secrets. No doubt an effort will be made to secure some modification of the decision in this case also. These, unfortunately, are not the only cases affecting aborigines which have attained notoriety and caused misgiving as to the judicial procedure in dealing with crimes and misdemeanours of aborigines. They point to the need of a special tribunal and a penal code ad hoc, which will take fully into account aboriginal culture and outlook on life, property and society. It is surely anomalous that while the Federal Government, for example, fosters continued tribal existence by securing to the aborigines the rights of access to traditional hunting grounds and water-holes, it forces them to abrogate tribal custom by submission to a code and tribunal appropriate to the civilisation and outlook of the white man.

\section{Excavations at Tell el-Amarna}

IN the season's excavations of the Egypt Exploration Society at Tell el-Amarna, which have recently been brought to a close, the most notable achievement has been the completion of the exploration of the great palace of Akhenaten, or rather of what was left of it by the spoilers by whom it was destroyed at the collapse of the Aton religion and the abandonment of the city. The building was of a remarkable size. It has now been shown by the recent excavation to have been little less than a kilometre in length. At the south end was a vast hall in which the roof was supported by six hundred square pillars of mud brick. The walls had been covered with faience tiles in green with a characteristic decoration of inlaid white daisies. Among the relics found in this building were a large number of fragments of huge statues. These evidently had occupied a position along a plaster pavement leading to a columned hall. They had apparently stood on the oblong bases which were found at intervals along this passage. It is to be concluded that the statues were hacked to pieces when the palace was destroyed. Near the palace entrance was a well-preserved copper crowbar, which, no doubt, had been used as one of the implements of destruction. Among the examples of the sculpture, for which the site is now famous, this season's finds included a remarkably fine head of Akhenaten executed in black granite.

\section{Bronze Age Burials near Bournemouth}

A Remarkable example of a bronze age barrow is now in course of excavation at Dudsbury, near Bournemouth. Its method of construction is believed to be unique in the British Isles. Beneath the sand and gravel forming the surface of the heath on which it is situated, it is stated by a correspondent of The Times in the issue of April 26, that Col. C. D. Drew, who is conducting the excavation, has found a mound of turves, three feet thick at the centre. No skeletal remains were found in this mound, which constitutes the primary interment. For this, the acidity of the soil is held responsible, all animal remains being destroyed by its action. A secondary interment took place in the top of this mound, and above it was piled a further six feet of turves with a top dressing of other soil. In the secondary interment was an inverted cinerary urn which had covered the ashes of the incinerated body. It is of Middle Bronze Age type (c. 2,000-1,500 B.c.) and has an ornamentation of three horizontal grooves running around it and finger-nail marks on the rim. It is about 16 inches high and 12 inches in diameter. It will be deposited eventually in the Dorchester Museum.

\section{Progress in Aero-Engine Design}

The Bristol Aeroplane Company has just completed the official tests of an improved engine, to replace the standard Pegasus III air-cooled radial 